\title{
Modifikasi Permainan Puzzle Sebagai Media Pembelajaran Ekonomi Berbasis Make A Match Kelas XI Untuk Meningkatkan Hasil Belajar
}

\author{
Vivi Feby Ariyawan \\ Program Studi Pendidikan Ekonomi \\ Universitas Negeri Surabaya \\ Surabaya, Indonesia \\ e-mail: vivi.17080554032@mhs.unesa.ac.id
}

\section{Riwayat Artikel Tanggal diajukan: 20 Mei 2021 \\ Tanggal diterima 5 Juni 2021 \\ Tanggal dipublikasikan: 25 Juni 2021}

Pengutipan:

Ariyawan, V.,

Feby (2021).

Modifikasi

Permainan

Puzzle Sebagai

Media

Pembelajaran

Ekonomi Berbasis

Make A Match

Kelas XI Untuk

Meningkatkan

Hasil Belajar.

Jurnal Pendidikan

Ekonomi

Undiksha, 13(1),

241-252

http://dx.doi.org/1 $0.23887 /$ ijpe.v13i

$\underline{1.34586}$

\begin{abstract}
Abstrak
Penelitian di latar belakangi karena belum ada media pembelajaran di sekolah untuk membatu proses belajar mengajar pada mata pelajaran ekonomi. Sering dijumpai motivasi belajar yang rendah pada perserta didik. Di kelas belum ketersediaan media pembelajaran yang medukung dan menaikkan hasil belajar peseta didik pada mata pelajaran ekonomi pada khususnya, maka penelitian ini mengembangkan media pembelajaran permainan puzzle berbasis make a match yang bertujuan untuk mengetahui kelayakan, keefektifan, kepraktisan media pembelajaran pada hasil belajar peserta didik. Penelitian ini adalah penelitian pengembangan dengan Four-D models yang hanya sampai pada tahap pengembangan (Develop). Desain uji coba penelitian ini memakai one group pretestpostest design. Subjek uji coba dalam penelitian ini adalah peserta didik SMA Negeri 3 Bojonegoro kelas XI IPS 1 sejumlah 24 peserta didik. Hasil penelitian ini memenuhi syarat layak, diperoleh kategori sangat layak sebesar $91 \%$ pada validasi media, diperoleh kategori sangat layak sebesar $100 \%$ pada validasi materi, diperoleh kategori layak sebesar $80 \%$ pada validasi evaluasi, diperoleh kategori sangat layak sebesar $100 \%$ pada validasi efektifitas, dan diperoleh kategori sangat layak sebesar $100 \%$ pada kepraktisan, diperoleh kategori sangat layak sebesar $95,07 \%$ pada respon peserta didik. Dari hasil penelitian dapat ditarik kesimpulan bahwa media pembelajaran permianan puzzle berbasis make a match yang dikembangkan layak, efektif dan praktis untuk digunakan.
\end{abstract}

Kata kunci: hasil belajar; media belajar; permainan; puzzle; make a match.

Abstract
Research is in the background because there is no learning media in
schools to help the teaching and learning process in economic
subjects. Often found low learning motivation in students. In the
classroom there is no learning media that supports and increases
student learning outcomes in economic subjects in particular, so this
study develops a make a match based puzzle game learning media
which aims to determine the feasibility, effectiveness, practicality of
learning media on student learning outcomes. This research is a
development research with Four-D models which only reaches the
Develop stage. The trial design of this study used a pretest-posttest
group design. The test subjects in this study were 24 students of SMA
Negeri 3 Bojonegoro, class XI IPS 1 . The results of this study met the
feasible requirements, obtained a very feasible category of $91 \%$ in


media validation, obtained a very feasible category of $100 \%$ in material validation, obtained a feasible category of $80 \%$ in the evaluation evaluation, obtained a very feasible category of $100 \%$ on the validation of effectiveness, and obtained a very feasible category of $100 \%$ in practicality, obtained a very feasible category of $95.07 \%$ in the response of students. From the research results it can be concluded that the learning media based on make a match puzzle games developed are feasible, effective and practical to use.

Keywords : learning outcomes; learning media; game; puzzle; make a match.

\section{PENDAHULUAN}

Hasil belajar merupakan salah satu baromater dari ketercapaian belajar. Hasil belajar akan tampak dari perubahan dari tingkah laku peserta didik setelah mereka mengikuti kegiatan belajar. Menurut Saifullah et al. (2017) ketercapain peserta didik dalam menguasai materi yang diajarkan saat di sekolah yang ditunjukkan dari perolehan nilai dan hasil tes terhadap penguasaan sejumlah materi yang diajarkan merupakan maksud dari hasil belajar dan dimana hasil belajar merupakan seluruh kecakapan yang dipunyai peserta didik selepas mereka mendapatkan pengetahuan belajar. Menurut Lin et al. (2019) setiap peserta didik melakukan kegiatan belajar dengan tingkat keterlibatan yang berbeda-beda sehingga akan berengaruh pada hasilnya pula. Ketika peserta didik telah melalui proses belajar maka mereka akan memperolah kompetensi-kompetensi yang baru serta tingkat keteribatan yang berbeda-beda saat belajar akan mempengaruhi hasil belajar pesera didik. Hasil belajar peserta didik dicerminkan melalui usaha belajar yang dilakukan, ketika peserta didik melaksanakan belajar dengan giat dan sungguh-sungguh lalu akan menyertakan hasil belajar yang positif, berupa nilai yang memuaskan.

Peserta didik agar mencapai hasil belajar yang baik, guru harus mencermati faktor-faktor pembelajaran yang salah satunya berupa media pembelajaran. Segala hal yang bisa menyokong guru dan peserta didik memperoleh tujuan pembelajaran adalah media pembelajaran (Seftis Rakhma W. et al., 2016). Media pembelajaran adalah alat penunjang kegiatan pembelajaran yang berlangsung dalam kelas. Sejalan dengan pendapat Tafonao (2018) media pembelajaran alat penunjang pembelajaran yang berguna untuk menarik perhatian peserta didik. Peserta didik akan mendapatkan kemudahan dalam menerima materi yang disajikan dengan memanfaatkan media pembelajaran. Media pembelajaran yang diciptakan oleh guru merupakan wujud dari usaha meningkatkan mutu pendidikan. Dengan adanya media pembelajaran sebagai alat penunjang pendidikan akan memudahkan peserta didik untuk mempelajari dan menguasai materi yang disampaikan.

Bersumber hasil wawancara bersama guru mata pelajaran ekonomi di SMAN 3 Bojonegoro kelas XI IPS diketahui bahwa hasil belajar peserta didik mengalami penurunan kurang lebih sebesar $50 \%$ pada tiap kelas khususnya pada mata pelajaran ekonomi, saat dilakukan sistem zonasi hingga saat ini. Hasil belajar peserta didik SMAN 3 Bojonegoro pada mata pelajaran ekonomi sangat jauh dari lulusan-lulusan sebelumnya. Dari hasil wawancara dengan guru ekonomi kelas XI IPS menjelaskan, hasil belajar mata pelajaran ekonomi rendah, peserta didik masih sukar dalam memahami. Sejumlah 18 sampai 22 peserta didik pada kelas XI IPS mengalami ketidak tuntasan dalam belajar materi ekonomi. Dalam menyampaikan materi ekonomi, guru menggunakan media pembelajaran berupa slide powerpoint yang sederhana. Media yang digunakan berupa slide powerpoint belum bisa meningkatkan hasil belajar siswa. Ketika menyampaikan materi dengan slide powerpoint di kelas XI IPS 1, dari sejumlah 36 peserta didik sejumlah 20 lebih peserta 
didik masih banyak dijumpai oleh guru tidak aktif dalam pembelajaran, 3 mengantuk, dan sisanya tidak memperhatikan serta berbicara dengan teman sebangku. Guru ekonomi juga menjelaskan bahwa membutuhkan media pembelajaran yang dapat mebuat peserta didik lebih antusias dan peserta didik dapat terlibat aktif dalam kegiatan belajar mengajar.

Penelitian ini memilih materi kerjasama internasional. Pada materi kerjasama internasonal peserta didik dituntut untuk menguasai konsep kerjasama internasional, dimana peserta didik diharuskan untuk memahami pengertian, bentu-bentuk dari kerjasama internasional, faktor-faktor, tujuan, manfaat serta lembaga kerjasama internasional, namun menurut yang disampaikan oleh guru pada kenyataanya peserta didik masih sukar untuk menguasai materi tersebut. Pada materi kerjasama internasional belum terdapat media pembelajaran yang membantu peserta didik untuk mempermudah memahami konsep yang harus dikuasai. Selain itu semangat peserta didik belum terbangkitkan untuk belajar materi tersebut. Materi kerjasama internasional sesuai dengan media permainan puzzle berbasis make a match karena terdapat persoalan yang harus dipecahkan dengan berkelompok, akan terjadi kerjasama antar peserta didik sehingga akan membuat semua peserta didik turut aktif berdiskusi dan membuat semangat belajarnya tergugah sebab terdapat permasalahan yang harus mereka selesaikan secara bersama-sama.

Berdasarkan permasalahan yang telah dipaparkan, maka sangat perlu dikembangkan media pembelajaran permianan puzzle berbasis make a match yang tepat yang sanggup memacu peserta didik aktif ketika belajar dan dalam menggunakan media pembelajaran mereka ikut terlibat langsung, sehingga membuat pembelajaran lebih bermakna dan terekam lebih lama dalam ingatan peserta didik yang akan mengakibatkan hasil belajar yang membaik. Maka penelitian ini memilih untuk mengembangakan media pembelajaran permainan puzze berbasis make a match.
Kegiatan belajar bisa lebih membangkitkan dorongan untuk belajar salah satunya dengan memanfaatkan media permaianan. Menurut Novia Arifin et al. (2018) kebiasaan yang selaras untuk mengajarkan suatu konsep pada peserta didik adalah dengan menggunakan permainan. Selaras juga dengan pendapat Genc \& Aydemir (2015) bahwa pemanfaatan game atau permainan di kelas membuat peserta didik untuk menghadapi belajar yang lebih aktif, sehingga pelaksanaan pembelajaran menggunakan permainan akan lebih efektif. Namun pada kenyataanya selama bermain game, peserta didik sebagai pemain akan menghadapi suatu permasalah yang harus mereka pecahkan agar mereka mencapai tujuannya, dimana kesalahan dan ketidakberhasilan akan mewarnai proses permainan tersebut (Kordaki \& Gousiou, 2017). Maka permainan adalah cara yang baik yang digunakan untuk menyampaikan materi dalam proses pembelajaran, dimana di dalamnya juga melibatkan aktivitas fisik selain itu peserta didik juga belajar untuk memecahkan sebuah masalah.

Puzzle merupakan permainan yang berupa potongan gambar. Menurut Widyatmoko (2019) puzzle adalah media permainan yang menyusun pecahan gambar acak menjadi satu kesatuan yang utuh. Sehingga puzzle merupakan permainan yang terdiri dari bagian-bagian gambar yang tersusun dan akhirnya membentuk satu kesatuan yang utuh. Puzzle menyajikan permasalahan kepada seseorang dimana masalah yang dihadapi adalah permasalahan yang sulit untuk diselesaikan (M Candiasa et al., 2018). Puzzle ini merupakan permainan yang menyajikan sebuah permasalahan untuk dapat dipecahkan, dimana perlu dicari kebenaran dengan melakukan penalaran untuk menemukan penyelesaian yang tepat. Penggunaan media pembelajaran puzzle yang menyajikan permasalahan akan memberikan rangsangan kepada peserta didik agar bisa aktif memecahkan dan dalam mengikuti pembelajaran. Puzzle dapat menarik minat dalam kegiatan pembelajaran, merubah suasana kelas lebih hidup, dan melalui gambar 
menumbuhkan pemikiran yang baik kepada peserta didik adalah manfaat dari puzzle (Sri Agus Setyaningsih \& Wahyuni, 2018). Tertariknya peserta didik terhadap suatu media pembelajaran yang membuat mereka senang maka akan membuat mereka antusias dalam mengikuti pembelajaran yang dilakukan.

Media pembelajaran puzzle ini menerapkan model pembelajaran make a match. Make a match adalah salah satu metode pembelajaran berupa permainan memanfaatkan kartu, dimana terdapat kartu jawaban dan soal dan peserta didik harus menemukan pasangan kartu yang sesuai dengan yang dimiliki. Menurut Al Mukarromah et al. (2019) model pembelajaran make a match bersifat kerjasama, dimana mencari pasangan kartu yang cocok dengan yang dimiliki untuk belajar suatu konsep dengan suasana yang menggembirakan. Dengan adanya kartu soal dan jawaban memungkinkan peserta didik saling berinteraksi dan bekerjasama untuk menentukan pasangan yang cocok dengan kartu yang dipegang. Interaksi yang terjadi antara peserta didik dapat melatih keterampilan sosialnya. Dengan menggunakan metode make a match maka dapat meningkatkan interaksi antar peserta didik, mendorong semangat belajar dan peserta didik dapat disiplin terhadap waktu (Agus Krisno Budiyanto, 2016).

Berdasarkan penelitian terdahulu Kristiana et al. (2017) menggunakan media puzzle dengan model pembelajaran TGT pada materi sistem eksresi mengungkapkan bahwa model dan media pembelajaran yang digunakan bisa memupuk keaktifan serta hasil belajar peserta didik menjadi meningkat. Diperoleh $76,66 \%$ kentuntasan belajar pada kelas ekperimen, sementara untuk kelas kontrol diperoleh $54,54 \%$. Diperoleh rata- rata keaktifan pada kelas kontrol adalah 56,55, pada kelas kontrol mendapat 80,57. Penelitian serupa juga dilakukan oleh Fatmawati \& Harmanto (2019) menunjukkan bahwa penggunaan media puzzle berbasis index card match memperoleh tingkat dengan nilai 95,45\% dari ahli media sedangkan diperoleh $92,85 \%$ dari ahi materi, sehingga tingkat kelayakan dari keduanya memperoleh kriteria sangat layak. sedangkan dalam keefektifan diperoleh nilai pretest sebesar 49,86 dan posttest sebesar 79.33 .

Sehingga dari latar belakang yang sudah diuraikan, maka diuraikan permasalahan antara lain: (1) bagaimana kelayakan media pembelajaran puzzle berbasis make a match pada hasil belajar pada mata pelajaran ekonomi peserta didik kelas XI, (2) bagaimana keefektifan media pembelajaran puzzle berbasis make a match terhadap hasil belajar pada mata pelajaran ekonomi peserta didik kelas XI, dan (3) bagaimana kepraktisan media pembelajaran puzzle berbasis make a match pada hasil belajar pada mata pelajaran ekonomi peserta didik kelas XI.

\section{METODE}

Penelitian ini merupakan penelitian pengembangan R\&D dengan desain 4D (Four $D$ Models) meliputi define (pendefinisian), design (perancangan), develop (pengembangan), dan disseminate (Lestari, 2018). Namun penelitian yang dilaksanakan berbatas hingga tahap pengembangan.

Desain uji coba penelitian ini menggunakan one group pretest-postest design (Sugiyono, 2015). Penelitian sebelumnya akan memberikan pre-test kepada kelompok sebelum diberikan perlakuan, lalu diberikan post-test setelah diberikan perlakuan. Subjek uji coba penelitian adalah peserta didik SMAN 3 Bojonegoro kelas XI IPS 1 sejumlah 24 peserta didik.

Instrumen yang digunakan berupa data kualitatif dan data kuantitatif. Komentar dan saran oleh para ahli agar bisa memperbaiki media pembelajaran diperoleh dari data kualitatif. Pada data kuantitatif diperoleh dari lembar validasi, angket respon peserta didik, dan soal pretest dan post-test. Data kelayakan produk media pembelajaran diperoleh dari lembar validasi para ahli materi dan media dengan menggunakan skala likert, sehingga bisa didapati kelayakan produk. Data keefektifan produk dapat dilihat pada nilai pre-test dan post-test peserta diidik, sehingga dapat diketahui kefektifannya. 
p-ISSN : 2599-1418

e-ISSN : 2599-1426

Data kepraktisan produk diperoleh dari hasil angket respon peserta didik dengan memakai skala guttman.
Jurnal Pendidikan Ekonomi Undiksha

Volume 13 No. 1 Tahun 2021

Teknik analisis data validasi dan respon peserta didik memakai kriteria intepretasi skor skala likert. Bisa diperhatikan pada tabel dibawah ini.

Tabel. Kriteria Intepretasi Skor

\begin{tabular}{cc}
\hline Skor kriteria & Kriteria \\
\hline $0 \%-20 \%$ & Sangat tidak layak \\
$21 \%-40 \%$ & Tidak layak \\
$41 \%-60 \%$ & Cukup layak \\
$61 \%-80 \%$ & Layak \\
\hline $81 \%-100 \%$ & Sangat layak \\
\hline \multicolumn{2}{c}{ Sumber : (Riduwan, 2016) }
\end{tabular}

Bersumber kriteria di atas diketahui bahwa perolehan skor dengan rentang 0\% sampai $20 \%$ dinyatakan sangat tidak layak, perolehan skor dengan rentang $21 \%$ sampai $40 \%$ dinyatakan tidak layak, perolehan skor $41 \%$ sampai $60 \%$ dinyatakan cukup, perolehan skor $61 \%$ sampai $80 \%$ dinyatakan layak, dan $81 \%$ sampai $100 \%$ dinyatakan sangat layak.

Pada teknik analisis data hasil belajar peserta didik, peneliti menggunakan kriteria ketuntasan klasikal seperti tabel dibawah ini.

Tabel 2. Kriteria Ketuntasan Klasikal

\begin{tabular}{cc}
\hline Persentase $(\%)$ & Kriteria interpretasi \\
\hline$<75 \%$ & Tidak tuntas \\
\hline$\geq 75 \%$ & Tuntas \\
\hline \multicolumn{2}{c}{ Sumber : (Syifaunnur, 2015) }
\end{tabular}

Bersumber kriteria intepretasi di atas dapat diketahui bahwa apabila persentase ketuntasan total peserta didik yang mencapai nilai di atas KMB sebesar $<75 \%$ maka ketuntasan klasikal dapat dinyatakan tidak tuntas dan ketika persetase ketuntasan total peserta didik yang mecapai nilai di atas KMB sebesar $\geq 75 \%$ maka ketuntasan klasikal dapat dinyatakan tuntas.

\section{HASIL DAN PEMBAHASAN}

Penelitian pengembangan ini menciptakan produk berupa media pebelajaran permainan puzzle berbasis make a match dengam menggunakan desain pengembangan 4D. Tahap awal berupa (defain): (a) analisi awal berupa pemilihan media yang serasi dengan karakteristik para peserta didik, (b) analisis karakter peserta didik yang dilangsungkan di kelas XI IPS 1 di SMA N 3 Bojonegoro. (c) analisis tugas peserta didik berupa soal yang ada pada media pembelajaran yang akan dijawab secara berkelompok serta soal pre-test dan post-test dalam struktur soal pilihan ganda disesuaikan dengan tingkat berfikir, (d) analisis materi yang akan digunakan yaitu KD 3.8 kerjasama internasional, (e) analisis tujuan pembelajaran yang disamakan dengan tujuan indikator kerjasama internasional.

Kedua adalah tahap perancangan desain (design): (a) penyusunan tes, dilakukan pre-test dan post-test sesuai kisikisi yang telah dibuat sebelumnya, (b) penentuan media yang sesuai untuk peserta didik yaitu media pembelajaran permainan puzzle berbasis make a match, (c) selanjutnya format media ini berisi penyajian soal untuk memperdalam pemahaman materi, (d) desain awal perupa rancangan dari media pembejaran permainan puzzle berbasis make a match.

Ketiga adalah pengembangan (develop) pada jenjang ini produk 
dihasilkan. Pada tahap ini pula dilakukan validasi media, materi, evaluasi, efektifitas dan kepraktisan: (1) validasi media dilakukan oleh satu dosen ahli dibidang media pembelajaran untuk mengetahui kelayakan media, (2) validasi materi dilakukan oleh satu dosen ahli materi untuk mengetahui kelayakan materi yang hendak diberikan kepada peserta didik, (3) validasi evaluasi dilakukan oleh satu dosen ahli evaluasi untuk mengetahui kelayakan bahan evaluasi media pembelajaran, (4) validasi efektifitas dilakukan oleh satu dosen ahli efektifitas untuk mengetahui kefektifan media yang hendak diberikan kepada peserta didik, dan (4) validasi kepraktisan dilakukan oleh satu dosen ahli kepraktisan untuk mengetahui kepraktisan media yang hendak diberikan kepada peserta didik. Validasi dilakukan untuk mengetahui nilai kelayakan, saran komentar berkaitan dengan media yang akan di implemtasikan.

Adapun penilaian yang diperoleh dari validasi media, materi, evaluasi, efektifitas dan kepratisan sebagai berikut.

Tabel 3. Hasil Validasi Media

\begin{tabular}{ccc}
\hline komponen & $\begin{array}{c}\text { Rata-rata } \\
\text { persentase(\%) }\end{array}$ & Kriteria \\
\hline keefektifan & $60 \%$ & Cukup layak \\
Penggunaan & $95 \%$ & Sangat layak \\
Komunkatif & $100 \%$ & Sangat layak \\
Huruf dan susunan & $100 \%$ & Sangat layak \\
Desain & $96 \%$ & Sangat layak \\
\hline Rata-rata media & $90,2 \%$ & Sangat layak \\
\hline
\end{tabular}

Bersumber tabel 3 di atas bisa ditemukan bahwa rata-rata persentase yang didapatkan dari hasil validasi media sebesar 90,2\% masuk dalam kelompok sangat layak.

Hasil validitas materi sebagai berikut.

Tabe 4. Hasil Validasi Materi

\begin{tabular}{ccc}
\hline Komponen & $\begin{array}{c}\text { Rata-rata } \\
\text { persentase(\%) }\end{array}$ & Kriteria \\
\hline Materi & $100 \%$ & Sangat layak \\
Interaktivitas & $100 \%$ & Sangat layak \\
Motivasi & $100 \%$ & Sangat layak \\
Sistematis & $100 \%$ & Sangat layak \\
Kualitas & $100 \%$ & Sangat layak \\
Kejelasan & $100 \%$ & Sangat layak \\
Evaluasi & $100 \%$ & Sangat layak \\
\hline Rata-rata persentase & $100 \%$ & Sangat layak \\
\hline
\end{tabular}

Bersumber tabel 4 di atas bisa ditemukan bahwa rata-rata persentase yang didapatkan dari hasil validasi materi sebesar $100 \%$ diterima dalam kelompok sangat layak. berikut.

Tabel 5. Hasil Validasi Evaluasi

\begin{tabular}{lcc}
\hline Komponen & $\begin{array}{c}\text { Rata-rata } \\
\text { persentase(\%) }\end{array}$ & Kriteria \\
\hline
\end{tabular}




\begin{tabular}{ccl}
\hline Materi & $80 \%$ & Layak \\
Kontruksi & $80 \%$ & Layak \\
Bahasa & $80 \%$ & Layak \\
\hline Rata-rata evaluasi & $80 \%$ & Layak \\
\hline
\end{tabular}

Bersumber tabel 5 di atas dapat diketahui bahwa rata-rata persentase yang didapatkan dari hasil validasi evaluasi sebesar $80 \%$ masuk dalam kategori layak.
Hasil validasi kefektifitasan sebagai berikut.

Tabel 6. Hasil Validasi Efektifitas

\begin{tabular}{ccc}
\hline Komponen & $\begin{array}{c}\text { Rata-rata } \\
\text { persentase(\%) }\end{array}$ & Kriteria \\
\hline Motivasi dan minat & $100 \%$ & Sangat layak \\
Fungsi media pembeajaran & $100 \%$ & Sangat layak \\
Reabilitas & $100 \%$ & Sangat layak \\
\hline Rata-rata kefektifan & $100 \%$ & Sangat layak \\
\hline
\end{tabular}

Bersumber tabel 6 di atas bisa ditemukan bahwa rata-rata persentase yang didapatkan dari hasil validasi efektifitas sebesar 100\% diterima dalam kategori sangat layak.

Hasil validasi kepraktisan sebagai berikut.

Tabel 7. Hasil Validasi Kepraktisan

\begin{tabular}{ccc}
\hline Komponen & $\begin{array}{c}\text { Rata-rata } \\
\text { persentase(\%) }\end{array}$ & Kriteria \\
\hline Kemanfaatan & $100 \%$ & Sangat layak \\
Kegunaan & $100 \%$ & Sangat layak \\
\hline Rata-rata kepraktisan & $100 \%$ & Sangat layak \\
\hline
\end{tabular}

Bersumber tabel 7 di atas ditemukan bahwa rata-rata persentase yang didapatkan dari hasil validasi kepraktisan sebesar $100 \%$ diterima pada kategori sangat layak.

Setelah mendapatkan kelayakan atas perolehan hasil validasi media, materi, evaluasi, keefektifan, dan kepraktisan, maka tahap selanjutnya dilakukan uji coba. Uji coba produk dilaksanakan dua tahap yaitu sebelum diterapkannya media dan setelah diterapkannya media pembelajaran permainan puzzle berbasis make a match. Sebelum dilakukan uji coba produk peserta didik diberikan soal pre-test. Berikut hasil pretest peserta didik.

Tabel 8. Hasil Pre-Test

\begin{tabular}{ccc}
\hline Nilai & Frekuensi & Keterangan \\
\hline $0-10$ & & Tidak tuntas \\
$11-20$ & & Tidak tuntas \\
$21-30$ & 2 & Tidak tuntas \\
$31-40$ & 3 & Tidak tuntas \\
$41-50$ & 3 & Tidak tuntas \\
$51-60$ & 4 & Tidak tuntas \\
$61-70$ & 6 & Tidak tuntas \\
$71-80$ & 4 & Tuntas \\
$81-90$ & 2 & Tuntas
\end{tabular}


$91-100$

Tuntas

$\%$ ketuntasan Tidak tuntas

Bersumber tabel 8 di atas dapat ditemukan bahwa peserta didik yang mengalami ketuntasan sebesar $25 \%$ atau sejumlah 6 peserta didik, dengan nilai terendah diperoleh sebesar 25 dan tertinggi sebesar 85 .

Tabel 9. Hasil Post-Test

\begin{tabular}{ccc}
\hline Nilai & Frekuensi & Keterangan \\
\hline $0-10$ & & Tidak tuntas \\
$11-20$ & & Tidak tuntas \\
$21-30$ & & Tidak tuntas \\
$31-40$ & & Tidak tuntas \\
$41-50$ & & Tidak tuntas \\
$51-60$ & & Tidak tuntas \\
$61-70$ & 2 & Tidak tuntas \\
$71-80$ & 8 & Tuntas \\
\hline $81-90$ & 9 & Tuntas \\
$91-100$ & 5 & Tuntas \\
\hline$\%$ ketuntasan & $91,66 \%$ & Tuntas \\
\hline
\end{tabular}

Bersumber tabel 9 di atas, bisa ditemukan bahwa peserta didik yang mengalami ketuntasan sebesar 91,66\% atau sejumlah 22 peseta didik, dengan nilai terendah diperoleh sebesar 65 dan tertinggi sebesar 100. Sehingga hal tersebut menunjukkan bahwa media
Tahap selanjutnya adalah setelah diterapkannya produk. pada jenjang ini peserta didik diberikan soal post-test. Berikut hasil post-test.

Tabel 10. Hasil Respon Peserta Didik

\begin{tabular}{ccc}
\hline Pertanyaan No & Persentase (\%) & Kategori \\
\hline 1 & $100 \%$ & Sangat layak \\
2 & $100 \%$ & Sangat layak \\
3 & $83,33 \%$ & Sangat layak \\
4 & $87,5 \%$ & Sangat layak \\
5 & $100 \%$ & Sangat layak \\
6 & $100 \%$ & Sangat layak \\
7 & $100 \%$ & Sangat layak \\
8 & $91,66 \%$ & Sangat layak \\
9 & $95,83 \%$ & Sangat layak \\
10 & $87,5 \%$ & Sangat layak \\
11 & $100 \%$ & Sangat layak \\
\hline Rata-rata respon & $95,07 \%$ & Sangat layak \\
\hline
\end{tabular}

Bersumber tabel 10 di atas dapat diketahui bahwa rata-rata respon peserta didik diperoleh sebesar $95,07 \%$ diterima kategori sangat layak. Maka dapat pembelajaran sangat efektif untuk diterapkan.

Setelah melakukan post-test peserta didik mengisi lembar angket respon untuk melihat ketertarikan peserta didik terhadap media yang telah diterapkan. Berikut hasil respon peserta didik. 
media pembelajaran sangat praktis untuk diterapkan.

\section{Pembahasan}

Kelayakan Media Pembelajaran

Permainan Puzzle Berbasis Make A Match

Pada kelayakan media dapat diperhatikan dari validasi media, materi dan evaluasi. Dari hasil validasi media memperoleh rata-rata sebesar 90,2\% diterima pada kelompok sangat layak, ratarata perolehan validasi materi sebesar $100 \%$ dalam kategori sangat layak, dan rata-rata perolehan validasi evaluasi sebesar $80 \%$ dalam kategori layak. Berdasarkan telaah yang diperoleh dari ahli materi kebijakan internasional yang akan diajarkan sesuai dengan topik, layak dan dapat dipergunakan untuk bahan ajar pada pembelajaran ekonomi di sekolah.

Menurut hasil analisis materi diketahuai bahwa untuk perolehan kualitas materi $100 \%$, interaktivitas $100 \%$, motivasi $100 \%$, sistematis $100 \%$, kualiatas $100 \%$, kejelasan $100 \%$, evaluasi $100 \%$. Maka perolehan rata-rata validasi media adalah $100 \%$ dalam kategori sangat layak. Dari analisis tersebut dapat disimpulkan bahwa materi kerjasama internasional pada media sangat layak untuk digunakan.

Menurut hasil analisis media diketahui kualitas keefektifan diperoleh $60 \%$, kualitas penggunaan $95 \%$, kualitas komunikatif $100 \%$, kualitas huruf dan susunan $100 \%$, dan kualitas desain $96 \%$. Maka didapatkan rata-rata validasi media adalah $90,2 \%$ diterima pada kelompok sangat layak. Dari hasil analisis bisa ditarik kesimpulan bahwa media pembelajaran permainan berbasis make a match sangat layak untuk digunakan.

Bersumber hasil telaah ahli evaluasi terdapat perbaikan yaitu berupa penyesuaian soal dengan tingkat kemampuan berpikir. Soal yang harus diperbaiki untuk disesuaikan dengan tingkat kemampuan berpikir terdapat pada nomor soal 5, 11, 12 dan 16.

Bersumber hasil analisis evaluasi diperoleh kualitas materi $80 \%$, kualitas kontruksi $80 \%$, kualitas bahasa $80 \%$. Sehingga perolehan rata-rata validasi media adalah $80 \%$ dalam kategori layak. Dari analisis tersebut bisa ditarik kesimpulan soal layak untuk dipakai sebagai bahan evalusi media pembelajaran permainan puzzle berbasis make a match.

Pada penelitian yang telah dilakukan oleh Rahayu Sesanti \& Sherly Arista Hasim (2018) menjelaskan bahwa rata-rata persetase validasi materi sebesar sebesar $85,3 \%$, dan validasi media sebesar $93,7 \%$. Sehingga dapat dikatan bahwa pengembangan media puzzle sogam (soal dan gambar ) pada materi penjumlahan dan pengurangan bilangan sangat layak untuk digunakan.

Pada penelitian Angger Barurroh (2019) juga mendapatkan rata-rata persentase validasi materi sebesar $83,89 \%$ dan validasi media sebesar $86,67 \%$. Sehingga bisa ditarik kesimpulan bahwa pengembangan media pembelajaran puzzle materi siklus hidup produk pada mata pelajaran marketing sangat layak untuk digunakan.

Berdasarakan perolehan hasil analisis data, jumlah dari perolehan hasil validasi media rata-rata sebesar 90,2\% diterima pada kelompok sangat layak, ratarata perolehan validasi materi sebesar $100 \%$ diterima pada sangat layak. Sehingga bisa ditarik kesimpulan media pembelajaran permainan puzzle berbasis make a match sangat layak untuk dimanfaatkan sebagai media pembelajaran di sekolah.

Keefektifan Media Pembelajaran Permainan Puzzle Berbasis Make A Match Kefektifan media pembelajaran dapat dilihat melalui hasil validasi efektifitas dan hasil belajarnya. Dari hasil validasi efektifitas diperoleh rata-rata sebesar $100 \%$ masuk dalam kategori sangat layak. Hasil analisis data pre-test menunjukkan bahwa peserta didik mengalami ketuntasan sebesar $25 \%$, dan hasil analisis data posttest menunjukkan bahwa peserta didik mengalami ketuntasan sebesar $91,66 \%$. Pembelajaran dapat dikatakan efektif jika nilai ketuntasan klasikal yang dicapai oleh peserta didik sebanyak $75 \%$ dari total keseluruhan. Sedangkan nilai KBM disekolah sebesar $\geq 75$.

Sebelum menerapkan media pembelajaran permainan puzzle berbasis 
make a match peserta didik diberikan soal pre-test terlebih dahulu. Hasil analisis data pre-test menunjukkan bahwa peserta didik mengalami ketuntasan sebesar $25 \%$ atau sejumlah 6 anak. Perolehan nilai terendah dari pre-test adalah 25 , sedangkan tertinggi adalah 85.

Setelah menerapkan media pembelajaran permaianan puzzle berbasis make a match peserta didik diberikan soal post-test. Hasil analisis data post-test menunjukkan bahwa peserta didik mengalami ketuntasan sebesar 91,66\% atau sejumlah 22 anak. Perolehan nilai terendah dari post-test adalah 65, sedangkan tertinggi adalah 100.

Dari hasil pre-test dan post-test, diketahui bahwa hasil belajar peserta didik mengalami peningkatan sebesar $66,66 \%$. Sebelum menerapkan media pembelajaran sejumlah 18 peserta didik mengalami ketidaktuntasan, sedangkan setelah menerapkan media pembelajaran hanya terdapat 2 peserta didik yang tidak tuntas.

Dari hasil validasi efektifitas diperoleh rata-rata sebesar $100 \%$ masuk dalam kategori sangat layak. Sehingga hal tersebut menunjukkan media pembelajaran sangat efektif untuk diterapkan.

Dari anaisis di atas, membuktikan bahwa media pembelajaran permainan puzzle berbasis make a match merupakan media yang efektif dan layak untuk diterapkan. Ketuntasan belajar yang dialami perserta didik menunjukkan bahwa media yang dikembangkan dapat menolong peserta didik dalam memahami materi.

Sesuai dengan Rahayu Sesanti \& Sherly Arista Hasim (2018) permainan puzzle merupakan media yang menarik dan menyenangkan sebab berupa potongan gambar yang haru diselesaikan, sehingga media tersebut dapat membantu perta didik dalam memahami materi yang disampaikan dan juga meningkatkan motivasi peserta didik dalam kegiatan belajar.

Menurut Genc \& Aydemir (2015) bahwa pemanfaatan game atau permainan di kelas membuat peserta didik akan mengalami proses pembelajaran yang lebih aktif, sehingga pelaksanaan pembelajaran menggunakan permainan akan lebih efektif.

Kerpraktisan Media Pembelajaran Permainan Puzzle Berbasis Make A Match Kepraktisan media pembelajaran dapat dilihat dari hasil validasi kepraktisan dan hasil respon peserta didik. Setelah sejumlah 24 peserta didik di kelas IPS 1 SMAN 3 Bojonegoro menerapkan media pembelajaran, peserta didik kemudian mengisi angket respon untuk mengetahui ketertarikan atau kesan peserta didik terhadap media.

Dari pengisian angket dapat diketahui bahwa rata-rata respon peserta didik diperoleh sebesar 95,07\% diterima pada kelompok sangat layak. Dapat ditarik kesimpulan untuk respon peserta didik terhadap media pembelajaran permainan puzzle berbasis make a match sangat baik.

Dari hasil validasi kepraktisan diperoleh rata-rata sebesar $100 \%$ diterima pada kelompok sangat layak. Sehingga hal tersebut menunjukkan bahwa media pembelajaran sangat praktis untuk diterapkan.

Hasil dari validasi dan respon peserta didik menunjukkan bahwa media yang diterapkan sangat bermanfaat dan berguna bagi peserta didik. Dengan menggunakan media pembelajaran permainan puzzle berbasis make a match motivasi belajar meningkat, membangkitkan ketertarikan belajar, serta membangun peserta didik ikut aktif.

Penggunaan media pada poses belajar bisa mempengaruhi hasrat untuk belajar dan juga mempengaruhi rasa ingin tahu yang semakin meningkat, selain itu motivasi belajar pada diri peserta didik juga semakin bertambah yang akan memberikan dampak pada psikologis peserta didik yang semakin baik (Sari et al., 2020).

Bersumberkan hasil analisis, ditarik kesimpulan (1) peserta didik lebih berperan aktif pada kegiatan belajar mengajar ketika memanfaatkan media pembelajaran, (2) semangat belajar yang sebelumnya kurang, menjadi lebih termotivasi dalam belajar setelah menerapkan media pembelajaran, (3) peserta didik 
dimudahkan menguasai materi dan membuat hasil belajarnya meningkat.

\section{SIMPULAN DAN SARAN}

Bersumber dari hasil penelitian ditarik kesimpulan yaitu (1) media pembelajaran permaian puzzle berbasis make a match sangat layak digunakan, dengan nilai ratarata diperolehan sebesar $90,2 \%$ pada kategori sangat layak, rata-rata perolehan validasi materi sebesar $100 \%$ diterima kategori sangat layak.(2) Media pembelajaran permaian puzzle berbasis make a match sangat efektif digunakan, dilihat dari nilai rata-rata validasi efektifitas sebesar $100 \%$ diterima kategori sangat layak, dan efektifitas diihat dari hasil belajar peserta didik mengalami kenaikan dari sebelumya $25 \%$ meningkat menjadi $91,66 \%$. (3) Media pembelajaran permaian puzzle berbasis make a match sangat praktis digunakan, dilihat dari nilai rata-rata validasi kepraktisan sebesar $100 \%$ dalam kategori sangat layak, dan respon peserta didik rata-rata diperoleh sebesar 95,07\% diterima pada kelompok sangat layak.

Pada media pembelajaran peneliti menyuguhkan soal untuk diselesaikan dengan berdiskusi, namun soal yang terdapat dalam media masih terbatas yaitu sejumlah 16 soal. Sehingga untuk memperdalam pemahaman materi pada media pembelajaran maka penelitian ini menyarankan untuk menambah jumlah soal dalam media pembelajaran.

\section{DAFTAR PUSTAKA}

Agus Krisno Budiyanto, M. (2016). SINTAKS 45 Metode Pembelajaran Dalam Student Centered Learning (SCL). Universitas Muhammadiyah Malang.

Al Mukarromah, N., Ristiono, Zulyusri, \& Hartanto, I. (2019). Pengaruh Penerapan Model Pembelajaran Make A Match Terhadap Hasil Belajar Peserta Didik Lintas Minat Tentang Materi Sistem Reproduksi pada Manusia Kelas XI IPS. Bioeducation Journal, 3, 93.

Angger Barurroh, T. (2019). Pengembangan Media Pembelajaran Puzzle Materi Siklus Hidup Produk Pada Mata Pelajaran Marketing Di
Kelas X Bisnis Daring Dan Pemasaran Smk Negeri 1 Lamongan. 07.

Fatmawati, F., \& Harmanto. (2019). Pengembangan Media Puzzle Berbasis Index Card Match Materi Peristiwa Lahirnya Pancasila Muatan IPS. Joyful Learning Journal, 8.

Genc, Z., \& Aydemir, emrah. (2015). An alternative evaluation: online puzzle as a course-end activity. Interactive Technology and Smart Education, 12, 170.

Kordaki, M., \& Gousiou, A. (2017). Digital Card Games in Education: a ten year systematic review. Computers \& Education, 1-2.

Kristiana, I., Nurwahyunani, A., \& Rita Sulistya Dewi, E. (2017). Pengaruh Model Pembelajaran TGT Menggunakan Media Puzzle Terhadap Keaktifan Dan Hasil Belajar Kognitif Siswa Pada Materi Sistem Ekskresi.

Lestari, N. (2018). Prosedural Mengoperasi Model 4D Dari Thiangrajan Suatu Studi Pengembangan LKM Bioteknologi Menggunakan Model PBL Bagi Mahasiswa. Jurnal IImiah Teknologi FST Undana, 12, 53.

Lin, L., Hung, I., Kinshuk, \& Chen, N. (2019). The impact of student engagement on learning outcomes in a cyber-fipped course.

M Candiasa, I., Santiyadnya, N., \& K A Sunu, G. (2018). Using puzzle to encourage students to do problem posing. Journal of Physics: Conference Series, 3.

Novia Arifin, A., Aldi, \& Reski Indah, F. (2018). Pengembangan Media Pembelajaran Genetic Vocabulary Cards Untuk Meningkatkan Motivasi dan Hasil Belajar Siswa. Jurnal Sainsmat, 7, 178-179.

Rahayu Sesanti, N., \& Sherly Arista Hasim, R. (2018). Media Puzzle SOGAM (Soal Dan Gambar) Pada Materi Penjumlahan Dan Pengurangan Bilangan. Jurnal Bidang Pendidikan Dasar (JBPD), 2, 92-96.

Riduwan. (2016). Skala pengukuran variabel-variabel penelitian. Bandung: Alfabeta.

Saifullah, R., Eprillison, V., \& Wati. (2017). 
Pengaruh Media Pembelajaran Konsep Diri Dan Cara Belajar Terhadap Hasil Belajar Siswa Kelas XI Pada Mata Pelajaran Ekonomi Di SMA Adabiah 2 Padang. Journal of Economic and Economic Education, 5, 158-161.

Sari, L., Angga Pratama, R., \& Intan Permatasari, B. (2020). Media Pembelajaran Puzzle Angka dan Corong Angka (PANCORAN) Bagi Anak Berkebutuhan Khusus (ABK). Jurnal Matematika Kreatif-Inovatif, 89-90.

Seftis Rakhma W., I., Widyaningsih, U., \& Mawartiningsih, L. (2016). Pengembangan Magic Crossword Puzzle Sebagai Media Pembelajaran IPA Untuk Siswa Kelas V Sekolah Dasar. Jurnal Refliksi Edukasi.

Sri Agus Setyaningsih, T., \& Wahyuni, H. (2018). Stimulus Permainan Puzzle Berpengaruh Terhadap Perkembangan Sosial Dan Kemandirian Anak Usia Prasekolah. Jurnal Keperawatan Silampari, 1, 72.

Sugiyono. (2015). Metode Penelitian Pendidikan (Pendekatan Kuantitatif, Kualitatif dan R\&D). Bandung: CV. Alfabeta.

Syifaunnur, H. (2015). Pengembangan Dan Analisis Kelayakan Multimedia Interaktif "Smart Chemist" Berbasis Intertekstual Seagai Media Pemebalajaran Kimia SMA.

Tafonao, T. (2018). Peranan Media Pembelajaran Dalam Meningkatkan Minat Belajar Mahasiswa.

Widyatmoko, H. (2019). TThe Development Of Educational Puzzle Game Based On The Local Wisdom Using Flash Media To Educate The Students'characteristic Of Primary School. Jurnal IImiah Kependidikan, 9, 193. 